\title{
Perempuan Sebagai Anak dan Hak-Haknya dalam Perkawinan \\ (Studi terhadap Peraturan Perundang-undangan dan Praktek di Pengadilan Agama) ${ }^{1}$
}

\author{
Oleh: Fatima \\ Dosen Universitas Satya Gama, Cengkareng, Jakarta \\ faza.roma@yahoo.com
}

\begin{abstract}
This paper aims to investigate how women or girls as daughters are administered in Islamic family laws and how they are awarded rights in regard to marriage. It also analyses how judges at Islamic courts solve the cases involving women as daughters. It, therefore, discusses how, according to Indonesian Islamic family law, women, as daughter could obtain permissions to get married when their parents are reluctant to marry them. It also discusses how they have also right to obtain permission to get married although they have not reached the minimum age of marriage. Investigating a number of judgments from Islamic courts of Central, South, West and East Jakarta and using socio-legal approach, this paper reveals that the proposal for marriage dispensation by parents at religious courts increased from year to year and that the proposals were often approved by judges. It also demonstrates that judges mostly conclude that the reluctance of parents to marry their daughters is based on legal reasons so that judges often decide to appoint 'wali hakim', as a substitute to 'wali nasab'.
\end{abstract}

\begin{abstract}
Abstrak
Paper ini bertujuan untuk menelusuri bagaimana perempuan sebagai anak memiliki posisi dalam hukum Islam keluarga dan bagaimana mereka mendapatkan hak-hak pernikahan. Paper ini juga menganalisa bagaimana para hakim di pengadilan agama menyelesaikan kasus terkait posisi perempuan sebagai anak. Paper ini, oleh karenanya, mendiskusikan bagaimana posisi perempuan dalam mendapatkan izin untuk menikah ketika orang tua mereka menolak untuk menikahkan. Tulisan ini juga mendiskusikan bagaimana anak perempuan berhak mendapat izin untuk menikah meskipun belum mencapai usia minimal pernikahan. Melalui penelusuran terhadap beberapa penilaian dari
\end{abstract}

\footnotetext{
${ }^{1}$ Artikel ini diintisarikan dari Tesis yang berjudul "Wanita dalam Hukum Keluarga Islam di Indonesia: Studi atas Kedudukan Wanita sebagai Ibu, Istri dan Anak, "Sekolah Pascasarjana UIN Syarif Hidayatullah Jakarta.
} 
Pengadilan Agama di Jakarta Pusat, Barat, Timur, dan Utara dengan menggunakan pendekatan Sosiologi Hukum, penelitian ini membuktikan bahwa pengajuan dispensasi nikah oleh orang tua di pengadilan agama terus meningkat dari tahun ke tahun dan pengajuan tersebut selalu dikabulkan oleh hakim. Para hakim kebanyakan menyimpulkan bahwa penolakan para orang tua untuk menikahkan anak perempuan mereka didasarkan pada alasan hukum sehingga hakim kerap kali memutuskan untuk menunjuk seorang 'wali hakim', sebagai pengganti 'wali nasab'.

Kata kunci: wali 'aḍal, anak perempuan, hukum Islam keluarga, wali hakim

\section{Pendahuluan}

Salah satu permasalahan yang muncul sebagai dampak dari modernisasi saat ini adalah pergaulan dan seks bebas yang disebabkan lunturnya nilai-nilai moral dan budaya, sehingga kehamilan di luar nikah menjadi konsekuensi yang harus diambil dan menjadi polemik keluarga terutama bagi orang tua. Bersandar pada budaya dan agama, kehamilan di luar nikah merupakan aib yang yang harus ditutupi, salah satunya adalah dengan menikahkan anak tersebut.

Dasar pertimbangan dalam menetapkan dispensasi perkawinan usia dini anak di bawah umur adalah Undang-Undang Perkawinan Nomor 1 Tahun 1974 yang membatasi usia pernikahan minimal 19 tahun untuk laki-laki dan 16 tahun untuk perempuan. Usia dan kedewasaan menjadi hal yang harus diperhatikan dalam pernikahan bagi laki-laki dan perempuan. Fakta di lapangan justru sebaliknya. Masyarakat tidak lagi mempertimbangkan usia dan kedewasaan sebagai syarat penting pernikahan, dikarenakan permasalahan moral yang sering terjadi.

Oleh karenanya, permohonan dispensasi nikah bagi mempelai di bawah umur semakin meningkat dari tahun ke tahun. Di Yogyakarta misalnya, data Pengadilan Agama Yogyakarta menunjukkan adanya kenaikan jumlah pemohon dispensasi nikah selama lima tahun terakhir. Tercatat di 2008 terdapat 21 pemohon dan 28 pemohon di 2009. Angka tersebut terus naik di 2010 menjadi 36 pemohon dan seterusnya hingga dua kali lipat di 2011 menjadi 61 pemohon. Kenaikan masih terjadi di tahun 2012 menjadi 66 pemohon dan hingga Maret 2013 sudah ada 12 pengajuan berkas permohonan ke PA Yogyakarta. ${ }^{2}$

Permasalahan juga terjadi saat pengajuan perkara permohonan dispensasi nikah dalam kasus calon mempelai perempuan yang telah hamil. Situasi dilematik ini dihadapi lembaga yudikatif, yang di satu sisi harus menegakkan

2“Permohonan Dispensasi Kawin di Bawah Umur Kian Meningkat di Yogyakarta”, diakses pada 25 April 2013 melalui www.Tribunnews.com

126 | INDO-ISLAMIKA, Volume 2, Nomor 1, 2012/1433 
hukum melarang pernikahan dini, tetapi di sisi lain terbentur dengan fakta kehamilan di luar nikah. ${ }^{3}$ Keput usan tersebut berdasarkan Pasal 53 KHI bahwa pernikahan dilakukan untuk menghindari kemudharatan dan merupakan hak perempuan untuk diinikahkan baik dengan laki-laki yang menghamilinya atau laki-laki lain.

Perempuan yang akan melangsungkan pernikahan harus memenuhi syarat dan rukun nikah, salah satunya adalah menghadirkan seorang wali nikah. Dalam kasus kehamilan di luar nikah, tidak selamanya anggota keluarganya setuju menjadi wali nikah dan setuju dengan pernikahan yang akan terjadi. Dengan demikian, calon mempelai perempuan dapat mengajukan permohonan wali 'aḍl ke Pengadilan Agama di tempat kediamannya. Majelis hakim akan memberikan pertimbangan hukum apakah yang menjadi alasan pengajuan wali 'aḍal tersebut berdasarkan hukum Islam dan Undang-undang Nomor 1 Tahun 1974 atau tidak.

Pengaturan mengenai pemenuhan hak anak diatur dalam Undang-Undang Nomor 23 Tahun 2002 tentang Perlindungan Anak yang meliputi hak tumbuh dan berkembang, hak sipil dan hak kebebasan, hak pengasuhan dan perawatan, hak bermain dan hak berpartisipasi, hak kesehatan, hak pendidikan serta perlindungan khusus. ${ }^{4}$ Hak yang dimaksud dalam penelitian ini adalah hak anak perempuan dalam perkawinan usia dini dan hak perempuan untuk dinikahkan meskipun tidak direstui walinya (wali 'aḍl).

Artkel ini bertujuan untuk melihat bagaimana perlindungan hak anak jika dijadikan sebagai subyek dalam perkawinan usia dini dan wali 'aḍal dilihat dari sisi peraturan perundang-undangan dan praktek di Pengadilan Agama dengan merujuk pada rentang waktu dua tahun yakni dari tahun 2010-2011. Meskipun diadakan pembatasan waktu, tidak menutup kemungkinan mengkaji pula putusan yang relevan dengan kajian ini. Putusan-putusan tersebut adalah putusan dispensasi nikah dan putusan wali 'aḍal di wilayah Pengadilan Agama DKI Jakarta saja yakni Pengadilan Agama Jakarta Selatan, Pengadilan Agama Jakarta Pusat, Pengadilan Agama Jakarta Barat, Pengadilan Agama Jakarta Utara dan Pengadilan Agama Jakarta Timur.

\section{A. Dispensasi Nikah dan Wali 'Aḍal dalam Peraturan Perundang- Undangan}

\section{Usia minimum dan dispensasi nikah}

\footnotetext{
${ }^{3}$ Fariha Aryani, "Pemberian Dispensasi Terhadap Perkawinan Perempuan Usia Dini dalam Keadaan Hamil dan Akibat Hukumnya Pada Pengadilan Agama Bantul” (Yogyakarta: Fakultas Hukum Universitas Islam Indonesia, 2011), 4-5.

${ }^{4}$ Undang - undang Nomor 23 Tahun 2002 tentang Perlindungan Anak, 2- 4.
} 
Banyak kasus yang menunjukkan bahwa angka perceraian yang tinggi cenderung didominasi oleh akibat pernikahan dini. Secara metodologis, langkah penentuan usia nikah didasarkan kepada metode maslahah al- mursalah yang berlandaskan fakta sosial. Ketentuan tersebut sifatnya ijtihadiyah yang kebenarannya relatif tidak bersifat kaku. Artinya, apabila karena sesuatu hal pernikahan dari mereka yang usianya di bawah ketentuan, Undang-undang tetap memberikan jalan keluar sebagaimana pasal 7 ayat (2) menegaskan, "Dalam hal penyimpangan terhadap ayat (1) pasal ini dapat meminta dispensasi kepada pengadilan atau pejabat lain yang ditunjuk oleh kedua orang tua pihak laki-laki maupun pihak perempuan. Dalam hal ini, Undang-undang Pernikahan tidak konsisten. Di satu sisi, pasal 6 ayat (2) menegaskan bahwa untuk melangsungkan pernikahan seseorang yang belum mencapai umur 21 (dua puluh satu) tahun harus mendapat izin dari kedua orang tua, di sisi lain pasal 7 (1) menyebutkan pernikahan hanya diizinkan jika pihak laki-laki sudah mencapai umur 19 (sembilan belas) tahun dan pihak perempuan sudah mencapai umur 16 (enam belas) tahun. Rupanya titik perbedaannya adalah jika kurang dari 21 tahun, yang diperlukan adalah izin orang tua, dan jika kurang dari 19 atau 16, perlu izin pengadilan. Ini dikuatkan oleh pasal 15 ayat (2) KHI. $^{5}$

Pengaturan usia dewasa lazimnya disimpulkan atau dikaitkan dengan Pasal 47 dan Pasal 50 UU No.1 Tahun 1974 Tentang Perkawinan. ${ }^{6}$ Mengenai Pasal 47 UU Perkawinan, Hazairin berpendapat bahwa, pasal tersebut membingungkan. Pasal ini menentukan seseorang telah menjadi dewasa pada usia 18 tahun, tetapi sekaligus menentukan kembali menjadi tidak dewasa jika Ia belum menikah. Pasal 47 UU Pernikahan tidak dapat dibaca seperti pasal 330 KUHPerdata (Kitab Undang-Undang Hukum Perdata), karena usia dewasa dalam KUHPerdata, ditentukan mereka yang sudah berusia 21 (dua puluh satu) tahun dan belum menikah. Apabila pernikahan mereka putus sebelum berusia 21 (dua puluh satu) tahun, maka mereka tidak kembali pada usia belum dewasa. $^{7}$

Sementara menurut Pasal 1 UU No. 23 Tahun 2002 tentang Perlindungan Anak menyebutkan bahwa, seseorang yang belum berusia 18 tahun masih termasuk anak-anak. Pasal 26 ayat 1 huruf (c) UU No. 23 Tahun 2002 tentang Perlindungan Anak, secara jelas juga menyebutkan bahwa orang tua berkewajiban dan bertanggung jawab mencegah terjadinya perkawinan di usia

\footnotetext{
${ }^{5}$ Ahmad Rofiq, Hukum Islam di Indonesia, (Jakarta: Raja Grafindo Persada), 78.

${ }^{6}$ Wahyono Darmabrata, Tinjauan Undang-Undang No.1 Tahun 1974 Tentang Pernikahan Berserta Undang-Undang dan Peraturan Pelaksanaannya, Cet. ke-2 (CV.Gitamaya Jaya, 2003), 26.

${ }^{7}$ Wahyono Darmabrata, Tinjauan Undang-Undang No.1 Tahun 1974 Tentang Pernikahan Berserta Undang-Undang dan Peraturan Pelaksanaannya, 113.
} 
anak-anak. Masih terdapat pintu keluar bagi penyimpangan terhadap ketentuan tersebut, seperti disebutkan dalam Pasal 7 ayat (2) yang memungkinkan pernikahan di bawah umur minimal pernikahan dengan mengajukan permohonan dispensasi nikah ${ }^{8}$ kepada Pengadilan.

\section{Perwalian Nikah dan Wali 'Aḍal}

Berdasarkan UU perkawinan di Indonesia, persetujuan mempelai perempuan merupakan syarat perkawinan ${ }^{9}$. Sedangkan wali menjadi salah satu rukun nikah. Sebagaimana terdapat dalam KHI pasal 19 ditegaskan bahwa wali nikah dalam perkawinan merupakan rukun yang harus dipenuhi bagi calon mempelai perempuan yang bertindak untuk menikahkannya. ${ }^{10}$

UU No. 1 Tahun 1974 tidak mengatur secara langsung tentang wali nikah. Ia hanya mengatur tentang izin pernikahan tanpa membedakan apakah izin itu dari orang tua laki-laki atau perempuan. Wali nikah secara khusus diatur dalam KHI. KHI secara tegas mewajibkan adanya wali dalam pernikahan. Meskipun demikian, tidak serta merta seorang wali dapat menikahkan anaknya, karena seorang wali harus memenuhi syarat tertentu sebagaimana penjelasan KHI pasal 20 sebagai berikut:

1. Yang bertindak sebagai wali nikah ialah seorang laki-laki yang memenuhi syarat hukum Islam yakni Muslim, aqil dan baligh. ${ }^{11}$

2. Wali nikah terdiri dari:

a. Wali nasab ${ }^{12}$

\footnotetext{
${ }^{8}$ Dispensasi usia pernikahan adalah pengurangan terhadap standar normatif yang diatur oleh Undang-Undang mengenai batas minimal usia pernikahan bagi seseorang yang akan melangsungkan pernikahan sebagaimana diatur dalam pasal 7 ayat (1) Undang- Undang Nomor 1 Tahun 1974.

${ }^{9}$ Pasal 6 UU No.1 Tahun 1974 tentang Perkawinan.

${ }^{10}$ Departemen Agama RI, Kompilasi Hukum Islam (Bandung: Citra Umbara, 2007).

${ }^{11}$ Pasal 20 angka (1) ini telah ditetapkan di dalam fikih, lebih-lebih lagi di dalam mazhab Syafi'i. Menurut Imam al-Bâjûrî, syarat yang harus dipenuhi bagi seorang wali adalah 1. Islam, 2. Baligh, 3. Berakal, 4. Merdeka, 5. Lelaki, 6. Adil (tidak fasik). Dari uraian Imam al-Bâjûrî ini ada dua yang tidak dicantumkan KHI; yaitu merdeka dan adil. Merdeka tidak dicantumkan karena memandang status merdeka sudah pasti wujud dan tidak perlu diqayyidkan karena memandang sekarang sudah tidak ada perhambaan. Sedangkan status adil tidak dicantumkan karena berpegang pada pendapat kedua di dalam mazhab Syafi'i, bahwa wali fasik tetap dapat menjadi wali nikah.

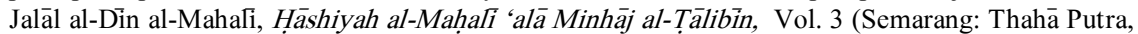
t.th.), 227.

${ }^{12}$ Sebagaimana Bunyi pasal 21 KHI yang menyatakan, (1) Wali nasab terdiri dari empat kelompok dalam urutan kedudukan, kelompok yang satu didahulukan dibandingkan kelompok lain sesuai erat tidaknya susunan kekerabatan dengan calon mempelai perempuan. Pertama, kelompok kerabat laki-laki garis lurus ke atas yakni ayah, kakek dari pihak ayah dan seterusnya. Kedua, kelompok kerabat saudara laki-laki kandung atau saudara laki-laki seayah, dan keturunan laki-laki mereka. Ketiga, kelompok kerabat paman, yakni saudara laki-laki kandung ayah, saudara seayah dan keturunan laki-laki mereka. Keempat, kelompok saudara laki-laki kandung kakek, saudara lakilaki seayah dan keturunan laki-laki mereka. (2) Apabila dalam satu kelompok wali nikah terdapat beberapa orang yang sama-sama berhak menjadi wali, maka yang paling berhak menjadi wali ialah
} 


\section{b. Wali hakim.}

Umumnya yang menjadi wali nikah adalah orang tua kandung. Jika memang orang tua berhalangan, bisa diwakilkan oleh kakek, saudara laki-laki dan seterusnya sebagai wali nasab. Jika semuanya berhalangan posisi wali nikah dapat digantikan dengan wali hakim. Selanjutnya, bagaimana jika ada orang tua tetapi tidak mau (enggan) menikahkan anaknya. Dalam kasus ini, harus dilihat dulu alasan keengganan wali untuk menikahkan anaknya. Apakah alasan tersebut berdasarkan $\operatorname{shar}^{5} i{ }^{13}$ atau alasan shar'i. Jika wali tidak mau menikahkan anak gadisnya dengan alasan yang tidak shar'i, maka wali tersebut disebut wali 'aḍl ${ }^{14}$ dan hak kewaliannya berpindah kepada wali hakim ${ }^{15}$ sebagaimana Peraturan Menteri Agama Nomor. 2 Tahun 1987 jo. Peraturan Menteri Agama Republik Indonesia Nomor 30 Tahun 2005 tentang tentang Wali Hakim, pasal 2 Ayat (1) dinyatakan bagi calon mempelai perempuan yang akan menikah di wilayah Indonesia atau di luar negeri atau di luar wilayah teritorial Indonesia, tidak mempunyai wali nasab yang berhak atau wali nasabnya tidak memenuhi syarat, atau mafqud, atau berhalangan, atau 'aḍl, maka pernikahannya dilangsungkan oleh wali hakim. Dan dalam Pasal 3 Ayat (1) juga disebutkan bahwa Kepala Kantor Urusan Agama Kecamatan (KUA) dalam wilayah kecamatan yang bersangkutan dapat ditunjuk menjadi wali

yang lebih dekat derajat kekerabatannya dengan calon mempelai perempuan. (3) Ababila dalam satu kelompok sama derajat kekerabatan maka yang paling berhak menjadi wali nikah ialah kerabat kandung dari kerabat seayah. (4) Apabila dalam satu kelompok, derajat kekerabatannya sama yakni sama-sama derajat kandung atau sama-sama dengan kerabat seayah, mereka sama-sama berhak menjadi wali nikah, dengan mengutamakan yang lebih tua dan memenuhi syarat-syarat wali.

Pada dasarnya, pasal 21 memiliki ketentuan yang terdapat di dalam fikih mazhab Syafi'i. Hanya saja, sistematika KHI menggunakan pembagian kelompok agar mudah difahami. Sedangkan sistematika yang biasa digunakan fikih mazhab Syafi'i klasik adalah langsung memberikan urutan wali (ترتيب الأولياء). Perlu dicermati, KHI tetap konsisten menetapi ketentuan fiqh Syafi'i di sini, karena pada angka (2), (3), dan (4) sudah ada klausul tertib sesuai urutan seperti dalam fikih Syafi'i sendiri. Lihat al-Jazirì, al-Fiqh 'alā al-Madhāhib al-Arba'ah, 827; Ibrāhīm al-Bājūīi, Hāashiyah alBājūri 'alāi ibn Qāsim al-Ghazzi, Vol. 2 (Surabaya: Hidâyah, t.th.), 105. Muhammad al-Shirbīini alHāțib, al-Iqnā'vol. 2, (Surabaya: al-Hidâyah, t.th.), 125

${ }^{13}$ Alasan shar'i adalah alasan yang dibenarkan oleh hukum shara', misalnya anak gadis wali tersebut sudah dilamar orang lain dan lamaran ini belum dibatalkan, atau calon suaminya adalah orang kafir (misal beragama Kriten/Katholik), atau orang fasik (misalnya pezina dan suka mabuk), atau mempunyai cacat tubuh yang menghalangi tugasnya sebagai suami, dan sebagainya. Jika wali menolak menikahkan anak gadisnya berdasarkan alasan shar'i seperti ini, maka wali wajib ditaati dan kewaliannya tidak berpindah kepada pihak lain (wali hakim). Lihat HAS Alhamdani, Risalah Nikah (Jakarta: Pustaka Amani, 1989), 90-91.

${ }^{14}$ Wali 'adal menurut A. Muki Arto adalah wali nasab yang mempunyai kekuasaan untuk menikahkan anak peempuannya yang berada dibawah perwaliannya, tetapi ia enggan atau tidak mau menikahkan sebagai layaknya seorang wali yang baik. Menurut Hoerudin adalah wali yang enggan atau wali yang menolak menjadi wali dalam pernikahan anak perempuannya dengan seorang laki-laki yang menjadi pilihannya. Lihat A. Muki Arto, Praktek Perkara Perdata pada Pengadilan Agama, 238. Lihat pula Ahrum Hoerudin, Pengadilan Agama (Bandung: Citra Aditya Bakti, 1999), 47.

${ }^{15}$ Abdurrahman Al-Jazirì, al-Fiqh 'alā al-Madhāhib al- 'Arba'ah, Juz IV, 33. 
hakim untuk menikahkan mempelai perempuan sebagaimana yang dimaksud dalam pasal 2 ayat (1).

Senada dengan Peraturan Menteri Agama, pasal 23 KHI juga menyebutkan sebagai berikut:

1. Wali hakim baru dapat bertindak sebagai wali nikah apabila wali nasab tidak ada atau tidak mungkin menghadirkannya atau tidak diketahui tempat tinggalnya atau gaib atau adlal atau enggan.

2. Dalam hal wali adlal atau enggan maka wali hakim baru dapat bertindak sebagai wali nikah setelah ada putusan pengadilan Agama tentang wali tersebut. $^{16}$

Kenyataan yang sering terjadi di masyarakat adalah bahwa seorang perempuan berhadapan dengan kehendak orang tuanya atau walinya yang berbeda, termasuk soal pilihan siapa yang hendak dijadikan menantu (suami). Ada yang sama-sama setuju, mengizinkannya, atau sebaliknya orang tua menolak kehadiran calon menantu yang telah menjadi pilihannya, karena telah mempunyai pilihan lain atau alasan lain. Sementara anak perempuan tersebut telah bersikeras untuk tetap menikah dengan calon suami pilihannya, sehingga untuk bisa tetap melangsungkan pernikahan, calon mempelai perempuan harus mengajukan perkara tersebut ke Pengadilan Agama setempat agar pengadilan memeriksa dan menetapkan wali 'aḍahnya, serta mengangkat wali hakim untuk menikahkannya setelah ada penetapan Pengadilan Agama tentang wali 'aḍlnya. ${ }^{17}$

\section{B. Menikah Muda melalui Dispensasi Nikah: Alasan dan Pertimbangan Hakim}

Tingginya tingkat pernikahan anak tidak terlepas dari hukum pernikahan yang longgar bagi pernikahan anak. Pasal 7 ayat (1) UU No. 1 Tahun 1974 tentang Pernikahan mengatur bahwa pernikahan hanya diizinkan jika pihak laki-laki sudah mencapai umur 19 tahun, dan pihak perempuan sudah mencapai umur 16 tahun.

Dari data yang diperoleh, wilayah DKI Jakarta saja dalam kurun waktu dua tahun yaitu dari tahun 2010 sampai 2011 permohonan dispensasi nikah yang diterima di Pengadilan Agama DKI Jakarta sudah mencapai 41 kasus, dengan rincian sebagaimana tabel dibawah ini.

\footnotetext{
${ }^{16}$ Kompilasi Hukum Islam (Bandung: Fokusmedia, 2005), 13.

${ }^{17}$ Lihat Peraturan Menteri Agama RI No. 2/1987 Pasal 6 Ayat (2), pasal 23 Ayat (2) KHI.
} 
Tabel: 4.3.

Perkara Permohonan Dispensasi Nikah yang diterima dan diputus Pengadilan

Agama DKI Jakarta Tahun 2010-2011

\begin{tabular}{|c|c|c|c|}
\hline No & $\begin{array}{c}\text { Pengadilan Agama } \\
\text { DKI Jakarta }\end{array}$ & Perkara Diterima & $\begin{array}{c}\text { Perkara } \\
\text { Diputus }\end{array}$ \\
\hline 1 & Jakarta Utara & 3 & 3 \\
\hline 2 & Jakarta Selatan & 15 & 11 \\
\hline 3 & Jakarta Timur & 12 & 11 \\
\hline 4 & Jakarta Pusat & 2 & 2 \\
\hline 5 & Jakarta Barat & 9 & 9 \\
\hline Jumlah & & 41 & 36 \\
\hline
\end{tabular}

Sumber: Pribadi Dari Laporan Tahunan Pengadilan Agama DKI Jakarta Tahun 2010-2011. ${ }^{18}$

Berdasarkan tabel di atas, dalam kurun waktu 2010 sampai 2011, permohonan dispensasi nikah yang diterima oleh Pengadilan Agama DKI Jakarta mencapai 41 kasus dan 36 diantaranya telah diputus. Data yang diterima tahun 2010 oleh Pengadilan Agama Jakarta Barat hanya 2 kasus dengan tambahan 2 kasus yang tidak selesai dari tahun sebelumnya. Sementara tahun 2011 perkara yang diterima berjumlah 7 kasus, dan kasus yang telah mendapat putusan adalah 5 kasus, sisanya dalam proses persidangan.

\section{Deskripsi kasus}

Putusan-putusan tersebut perlu dianalisa lebih lanjut apakah yang menjadi dasar dan pertimbangan hakim dalam mengabulkan permohonan dispensasi nikah. Apakah dari sekian banyak putusan-putusan dispensasi nikah yang telah diputus sudah memenuhi kriteria yang telah ditetapkan peraturan perundangundangan, atau hakim dengan kewenangannya melakukan terobosan hukum (ijtihad) guna tercapaian prinsip keadilan. Untuk mengetahui dasar dan

\footnotetext{
${ }^{18}$ Lihat Sufyan, "Laporan Tahunan 2010 Pengadilan Agama Kelas I.A Jakarta Utara tentang Perkara yang diterima dan diputus", (Jakarta, 31 Desember, 2010). Lihat pula Sufyan, "Laporan Tahunan 2011 Pengadilan Agama Kelas I.A Jakarta Utara tentang Perkara yang diterima dan diputus", (Jakarta, 31 Desember 2011). Lihat Ach Jufri dan Ahmad Majid, "Laporan Perkara yang diterima dan diputus Pengadilan Agama Jakarta Pusat Bulan Januari-Desember Tahun 2010". Lihat Ujang Mukhlis, "Laporan Perkara yang diterima dan diputus Pengadilan Agama Jakarta Pusat Bulan Januari-Desember Tahun 2011”. LIhat Ach Jufri, “ Laporan Pengadilan Agama Jakarta Selatan tentang Perkara yang diterima dan diputus Tahun 2010”, (Jakarta, 30 Desember, 2010). Lihat Ahmad Majid, "Laporan Pengadilan Agama Jakarta Selatan tentang Perkara yang diterima dan diputus Tahun 2011", (Jakarta, 30 Desember, 2011). Lihat Arsip "Data Perkara Pengadilan Agama Jakarta Barat Tahun 2010”, 27-29. Lihat Arsip "Data Perkara Pengadilan Agama Jakarta Barat Tahun 2011", 14-18. Lihat http://www.infoperkara.Badilaq.go.id. Di akses pada tanggal 2 Agustus 2011.
}

132 | INDO-ISLAMIKA, Volume 2, Nomor 1, 2012/1433 
pertimbangan hakim dalam memutus pemohonan dispensasi nikah, terlebih dahulu akan dijelaskan di sini mengenai kronologis alasan pengajuan dispensasi nikah. Berikut hasil temuan penulis terkait putusan penetapan permohonan dispensasi nikah.

Dari hasil penelitian yang telah dilakukan penulis, ternyata pengajuan permohonan dispensasi nikah di Pengadilan Agama DKI Jakarta disebabkan oleh dua faktor, yaitu karena calon mempelai perempuan telah hamil terlebih dahulu, dan adanya kekhawatiran dari orang tua akan terjadi hal-hal yang dilarang dalam agama seperti kehamilan di luar nikah. ${ }^{19}$ Sebagaimana permohonan yang disampaikan seorang pemohon pada tanggal 15 Maret 2010 yang terdaftar di Kepaniteraan Pengadilan Agama Jakarta Pusat dengan register perkara Nomor 19/Pdt.P/2010/PAJP. Pemohon hendak menikahkan anak kandungnya yang pada saat perkara ini diajukan umur anak laki-lakinya tesebut berumur 18 tahun 6 bulan, sedangkan calon istrinya berumur 19 tahun.

Dalam positanya, pemohon menjelaskan bahwa syarat-syarat untuk melaksanakan pernikahan tersebut baik menurut ketentuan hukum Islam maupun peraturan perundang-undangan yang berlaku telah terpenuhi kecuali syarat usia bagi anak para pemohon belum mencapai umur 19 tahun. Pernikahan tersebut sangat mendesak untuk dilangsungkan karena keduanya telah bertunangan selama 2 tahun dan hubungan mereka telah sedemikian erat, sehingga pemohon khawatir akan terjadi perbuatan yang dilarang oleh ketentuan hukum Islam. Untuk menguatkan dalil-dalil permohonannya tersebut pemohon telah mengajukan alat-alat bukti tertulis dan menghadirkan 2 (dua) orang saksi di muka persidangan. Berdasarkan fakta tersebut Majelis hakim berpendapat bahwa permohonan tersebut patut untuk dikabulkan. ${ }^{20}$

Kasus selanjutnya adalah permohonan dispensasi nikah yang disampaikan oleh Fadli (43 tahun) ke Pengadilan Agama Jakarta Barat pada tanggal 08 Mei 2012 dengan register perkara nomor 33/Pdt.P/2012/PAJB. Dalam positanya dijelaskan bahwa pemohon hendak menikahkan anak laki-lakinya yang masih berumur 18 tahun, sedangkan calon isterinya berumur 17 tahun. Alasan

\footnotetext{
${ }^{19} \mathrm{Di}$ daerah lain, ada beberapa faktor lain yang menjadi sebab diajukannya dispensasi usia pernikahan. Sebab- sebab tersebut antara lain, karena adat istiadat masyarakat sekitar yang terbiasa menikahkan anaknya di usia muda, bahkan usia anak- anak asalkan dianggap sudah pantas untuk menikah. Hal ini biasa terjadi di Madura. Selanjutnya, karena alasan ekonomi. Kondisi ekonomi masyarakat yang lemah, menyebabkan orang tua tidak bisa menyekolahkan anaknya ke jenjang yang lebih tinggi dan memilih menikahkan anaknya agar beban hidupnya berkurang. Terakhir, karena tingkat pendidikan masyarakat yang rendah sehingga tidak memiliki keinginan dan motivasi untuk memfasilitasi anak- anaknya agar lebih maju. Seperti misalnya keluarga dengan pemikiran tradisional terhadap anak perempuan yang tidak perlu memiliki pendidikan tinggi. Lihat Iin Wahyuni, "Dasar dan Pertimbangan Hakim Mengabulkan Dispensasi Usia Pernikahan ( Studi di Pengadilan Agama Kota Malang” (Malang: Fakultas Hukum Universitas Brawijaya, 2009), 71.

${ }^{20}$ Dokumen Putusan Pengadilan Agama Jakarta Pusat Nomor 19/Pdt.P/2010/PAJP.
} 
permohonan tersebut karena keduanya telah lama menjalin hubungan dan mengantisipasi kesulitan-kesulitan administrasi yang mungkin timbul di kemudian hari. Pemohon dan keluarga calon istri telah mengurus administrasi dan pendaftaran anak pemohon dengan calon istrinya, ke instansi terkait, namun pihak Kantor Urusan Agama Kecamatan setempat belum dapat menyelenggarakan pencatatan penikahan keduanya dengan alasan calon suami belum mencapai usia minimum pernikahan yakni 19 tahun. Pemohon dengan keluarga calon besan telah sepakat untuk memberikan izin untuk menikah.

Untuk mengukuhkan dalil-dalil yang telah diajukan, pemohon menyerahkan alat bukti berupa surat asli yang dikeluarkan Kantor Urusan Agama setempat yang menyatakan belum tepenuhinya persyaratan untuk melaksanakan pernikahan anak kandung pemohon karena belum mencapai umur 19 tahun. Selain bukti berupa surat, pemohon juga menhadirkan dua orang saksi yang membenarkan dalil-dalil yang dikemukakan pemohon. Berdasarkan fakta tersebut, majelis hakim dalam pertimbangannya berpendapat bahwa permohonan Pemohon patut untuk dikabulkan. ${ }^{21}$

Dalam kasus pengajuan dispensasi nikah yang disebabkan calon mempelai telah hamil di luar nikah, hampir seluruh penetapan dispensasi nikah yang dikeluarkan Pengadilan Agama DKI Jakarta dalam positanya sering kali, bahkan dapat dikatakan mayoritas pemohon, tidak mencantumkan alasan bahwa calon mempelai perempuan telah hamil di luar nikah. Padahal pada umumnya permohonan dispensasi nikah ke Pengadilan Agama dikarenakan calon mempelai perempuan telah hamil di luar nikah. ${ }^{22}$

Lain halnya dengan penetapan yang dikeluarkan Pengadilan Agama Malang yang dalam positanya pemohon menyebutkan secara jelas bahwa alasan pengajuan dispensasi nikah tersebut karena hamil di luar nikah sepeti kasus Nomor: 42/Pdt.P/2009/PA.Mlg. Dalam kasus ini, pemohon merupakan orang tua dari seorang anak perempuan yang masih berusia 14 tahun 5 bulan. Pemohon telah datang atau melapor ke kantor Pegawai Pencatat Nikah Kantor Urusan Agama (PPN KUA) di tempat dia tinggal untuk mencatatkan pernikahan anaknya, namun ditolak dengan alasan belum cukup umur. Anak pemohon mencintai seorang laki-laki yang berusia 21 tahun 4 bulan dan telah berpacaran selama 8 bulan. Selama berpacaran, hubungan mereka sudah sangat intim dan pernah melakukan hubungan suami istri yang mengakibatkan si

\footnotetext{
${ }^{21}$ Dokumen Putusan Pengadilan Agama Jakarta Barat Nomor 33/Pdt.P/2012/PAJB.

${ }^{22}$ Inilah bedanya antara legal justice dengan moral justice. Maksud legal justice disini karena belum mencapai syarat usia minimal nikah, moral justice kerena alasan hamil di luar nikah. Moral justice ini di luar wewenang hakim. Hakim terikat dengan hukum acara, hakim tidak boleh memutus melebihi dari tuntutan. Sepanjang syarat (legal Justice) sudah terpenuhi hakim sudah dapat memberi izin dispensasi nikah. Wawancara dengan M. Rizal, Hakim Pengadilan Agama Jakarta Barat, di ruang Hakim, pada tanggal 18 Juli 2012.
} 
perempuan hamil 7 bulan. Berdasarkan alasan tersebut, pemohon mengajukan permohonan dispensasi nikah ke Pengadilan Agama Kota Malang. ${ }^{23}$

Kekhawatiran orang tua dalam hal ini dikarenakan hubungan percintaan anaknya sudah sangat intim. Bisa dikatakan, bahwa si anak sudah tidak dapat dipisahkan lagi dengan pacarnya. Hubungan anak- anak mereka yang sudah terlalu dekat, membuat orang tua merasa khawatir akan terjadi hal-hal yang tidak diinginkan, misalnya si perempuan hamil terlebih dahulu. Orang tua lebih memilih jalan aman dengan cara menikahkan mereka sebelum hal yang dikhawatirkan itu terjadi. Seperti terjadi dalam kasus Nomor: 16/Pdt.P/2009/PA.Mlg. Dalam kasus ini, pemohon adalah orang tua dari anak laki-laki yang berusia 18 tahun. Pemohon berencana akan menikahkan anak laki- lakinya ini, sehingga dia datang ke kantor Pegawai Pencatat Nikah Kantor Urusan Agama (PPN KUA) untuk mencatatkan pernikahan anaknya, namun, keinginan pemohon ini ditolak dengan alasan anaknya belum cukup umur. Anak laki-lakinya ini memiliki pacar berusia 26 tahun. Mereka sudah berpacaran selama 1 tahun. Hubungan keduanya sudah sangat intim dan telah tinggal satu rumah selama 2 bulan. Bahkan, mereka telah melakukan hubungan suami istri selama tinggal dalam satu rumah. Pemohon takut akan terjadi hal-hal yang tidak diinginkan sehingga pemohon menginginkan anaknya segera menikah dengan calon istrinya demi kebaikan mereka berdua kelak. Keinginan pemohon untuk segera menikahkan anaknya terhambat menyangkut usia anak pemohon yang masih belum mencapai usia sesuai ketentuan peraturan perudangundangan yang berlaku.

Berdasarkan alasan tersebut, maka pemohon mengajukan permohonan dispensasi usia pernikahan ke Pengadilan Agama Kota Malang. Kondisi semacam ini di dalam masyarakat biasa disebut dengan istilah "kumpul kebo". Permohonan dispensasi pernikahan dalam kasus di atas, diajukan oleh orang tua anak laki- laki yang belum cukup umur untuk menikah karena orang tua khawatir akan terjadi kehamilan sebelum pernikahan. Selain itu, orang tua sudah tidak bisa menghentikan anaknya untuk tidak tinggal satu rumah lagi dan melakukan hubungan suami istri, sehingga, untuk menghindari dampak lanjutan yang lebih buruk, maka orang tua mengajukan permohonan dispensasi usia pernikahan ke Pengadilan Agama Kota Malang agar anaknya yang masih berusia 18 tahun bisa mengawini pacarnya. ${ }^{24}$ Pada umumnya Pengadilan Agama, seperti untuk kasus ini, dalam kasus permohonan dispensasi nikah dalam amar putusannya mengabulkan permohonan

\footnotetext{
${ }^{23}$ Iin Wahyuni, "Dasar dan Pertimbangan Hakim Mengabulkan Dispensasi Usia Pernikahan (Studi di Pengadilan Agama Kota Malang”, 64-65.

${ }^{24}$ Iin Wahyuni, "Dasar dan Pertimbangan Hakim Mengabulkan Dispensasi Usia Pernikahan (Studi di Pengadilan Agama Kota Malang)", 68-69.
} 


\section{Dasar dan Pertimbangan Hakim dalam Putusan Penetapan Permohonan Dispensasi Nikah}

Dalam kasus dispensasi nikah, 99\% majelis hakim mengabulkan permohonan dispensasi nikah ${ }^{25}$ dengan dasar dan pertimbangan-pertimbangan yang akan dijelaskan pada bagian selanjutnya.

Dalam memutuskan sebuah perkara, hakim harus memiliki dasar yang kuat agar keputusannya dapat dipertanggungjawabkan. Hakim wajib mencantumkan dasar pertimbangan yang cukup dan matang dalam setiap keputusan. Demikian secara singkat makna kewajiban tersebut, yakni putusan harus jelas dan cukup motivasi pertimbangannya. Dalam pengertian luas, bukan hanya sekedar meliputi motivasi pertimbangan tentang alasan-alasan dan dasar- dasar hukum serta pasal-pasal peraturan yang bersangkutan, tetapi juga meliputi sistematika, argumentasi dan kesimpulan yang terang dan mudah dimengerti orang yang membacanya. ${ }^{26}$

Dasar yang digunakan hakim dalam mengabulkan dispensasi nikah adalah ketentuan pasal 7 ayat (1) dan (2) UU No. 1 tahun 1974 jo. Pasal 15 ayat (1) KHI yang menyatakan bahwa pernikahan hanya diizinkan jika pihak laki-laki belum mencapai umur 19 tahun dan perempuan belum mencapai 16 tahun. Dalam hal penyimpangan terhadap ketentuan ayat (1) mengenai batas usia minimal untuk menikah, dapat meminta dispensasi kepada Pengadilan Agama atau pejabat lain yang ditunjuk oleh kedua orang tua pihak laki- laki maupun pihak perempuan. Pasal 7 ayat (2) ini memberikan kewenangan kepada hakim untuk mengabulkan permohonan dispensasi usia pernikahan karena Pengadilan Agama merupakan lembaga yang berwenang menangani permohonan usia pernikahan. Dalam setiap penetapan hakim untuk kasus permohonan dispensasi usia pernikahan, selalu dicantumkan Pasal 7 ayat (1) dan (2) UU Pernikahan jo. Pasal 15 ayat (1) Kng merupakan legitimasi bagi hakim yang diatur dalam Undang- Undang.

Perkara permohonan dispensasi nikah ini termasuk dalam bidang pernikahan maka berdasarkan pasal 89 ayat (1) UU No. 7 Tahun 1989 tentang Peradilan Agama, yang telah diubah dan ditambah dengan UU No. 3 Tahun 2006 dan telah diubah dengan UU No. 50 Tahun 2009 pula biaya perkara dibebankan kepada pemohon atau penggugat. Inilah bedanya dengan hukum acara perdata pada umumnya, khusus pada bidang pernikahan dan perceraian

\footnotetext{
${ }^{25}$ Wawancara dengan M. Rizal, Hakim Pengadilan Agama Jakarta Barat, di ruang Hakim, pada tanggal 18 Juli 2012.

${ }^{26}$ M. Yahya Harahap, Kedudukan, Kewenangan dan Acara Peradilan Agama UU No. 7 Tahun 1989, 313.
}

136 | INDO-ISLAMIKA, Volume 2, Nomor 1, 2012/1433 
biaya perkara dibebankan kepada pemohon atau penggugat selaku pencari keadilan $^{27}$

Berdasarkan temuan penulis dari hasil wawancara terhadap hakim PA DKI Jakarta, bahwa mayoritas alasan permohonan dispensasi nikah dikarenakan telah terjadi kehamilan di luar perkawinan. Menurut penulis putusan Majelis Hakim mengabulkan permohonan dispensasi usia pernikahan sangatlah tepat guna untuk menghindari keburukan yang akan terjadi dimasa

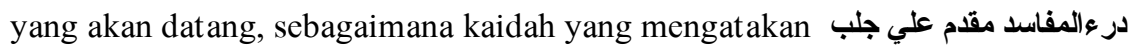
(menghindari kerusakan harus didahulukan daripada mempertahankan kebaikan). Hal ini dikarenakan pernikahan adalah sesuatu yang sangat mendesak dan harus segera dilakukan agar status kedua calon mempelai jelas dan status anak yang akan dilahirkan nanti juga jelas. Apabila permohonan dispensasi usia pernikahan tidak dikabulkan dalam kondisi tersebut, maka akan terjadi kerugian yang angat besar yang akan dialami oleh calon mempelai perempuan dan anak yang ada di dalam kandungannya. Anak dalam kandungan perempuan tersebut bisa jadi tidak akan mempunyai ayah yang sah saat dia dilahirkan nanti. Hal ini memiliki dampak lanjutan yang cukup panjang seperti, dalam hal pengurusan akte kelahiran dan dokumen- dokumen lain yang akan digunakan untuk mendukung masa depan calon anak tersebut. Selain itu, adanya hukuman dari masyarakat berupa gunjingan dan mungkin saja pengasingan dari lingkungan sekitarnya karena dianggap sebagai "anak haram", serta dampak- dampak lain yang akan sangat merugikan masa depan calon anak tersebut.

Adanya dispensasi bagi calon mempelai yang kurang dari sembilan belas bagi laki-laki dan enam belas tahun bagi perempuan, boleh jadi didasarkan kepada hadits Nabi ketika menikahi Aisyah. Kendati pun kebolehan tersebut harus dilampiri izin dari pejabat untuk itu. Ini menunjukkan bahwa penanaman konsep pembaharuan hukum Islam yang memang bersifat ijtihāàiyah, diperlukan waktu dan usaha terus-menerus. Ini dimaksudkan, pendekatan konsep maslahah al-mursalah dalam Hukum Islam di Indonesia, memerlukan waktu agar masyarakat sebagai subyek hukum dapat menerimanya dan menjalankannya dengan sukarela tanpa ada unsur pemaksaan. ${ }^{28}$

Perlu disebutkan bahwa salah satu faktor orang tua menikahkan anak di usia dini adalah faktor budaya. Masalah kemiskinan menjadi faktor lain yang mendorong orang tua untuk segera menikahkan anak perempuan mereka. Dengan menikahkan anak, orang tua dapat terbebas dari beban ekonomi untuk

\footnotetext{
${ }^{27}$ A. Mukti Arto, Praktek Perkara Perdata pada Pengadilan Agama, 224.

${ }^{28}$ Sudirman, "Pembatasan Usia Minimal Pernikahan: Upaya Meningkatkan Martabat Perempuan”, (Malang: Fakultas Syariah UIN Malang), 12.
} 
menanggung biaya hidup anak. Kondisi ekonomi suatu keluarga akan mempengaruhi tingkat pendidikan anak sehingga dapat menunda terjadinya pernikahan anak. Oleh karena itu, pemberdayaan ekonomi masyarakat merupakan upaya penting untuk menekan tingkat pernikahan anak. Selain itu gerakan orang tua asuh juga perlu digalakkan untuk membantu pendidikan anak-anak yang berasal dari keluarga tidak mampu.

Hal ini sangat terkait dengan teori pemberlakuan hukum di mana budaya hukum, yaitu kebiasaan atau tradisi dalam masyarakat, mempunyai peran penting. Budaya masyarakat dalam hal pernikahan dini dipengaruhi oleh nilainilai yang diyakini oleh masyarakat. Bagi masyarakat Muslim, terkait dengan pernikahan dini, memang terdapat hadis yang diriwayatkan oleh Hisyam ibn 'Urwah, yang sering kali dijadikan dasar atau dalil atas kebolehan pernikahan dini. Dalam hadis tersebut diceritakan bahwa Aisyah menikah dengan Rasulullah SAW pada usia 7 tahun, dan mulai berhubungan badan dengan Rasulullah saw pada usia 9 tahun. Riwayat Hisyam ibn 'Urwah tidak dapat dijadikan hujjah untuk zaman sekarang. ${ }^{29}$ Nabi hidup pada masa tradisi budaya Arab di mana pernikahan anak di bawah umur sudah biasa terjadi dan bukan dianggap hal aneh, apalagi dianggap sebagai kejahatan terhadap anak-anak di bawah umur. ${ }^{30}$ Berbeda dengan masa sekarang, kehidupan masyarakat terus berubah sesuai dengan perkembangan zaman, maka berubah pula budaya suatu masyarakat yang pada akhirnya diikuti pula dengan perubahan hukum sesuai

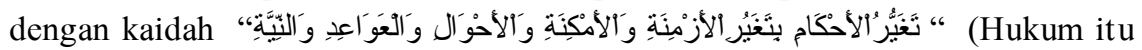
berubah sesuai dengan perubahan waktu, tempat, keadaan, adat dan niat). ${ }^{31}$ Aturan mengenai batasan usia perkawinan merupakan salah satu aspek reform (norma baru) KHI atas kitab fikih klasik. ${ }^{32}$ Adanya peraturan batasan usia berkawinan menunjukkan bahwa praktek pernikahan dini merupakan pelanggaran kecuali ada alasan-alasan tertentu yang mengharuskan untuk dinikahkan sebagaimana beberapa kasus yang telah diuraikan di atas.

\footnotetext{
${ }^{29}$ Sebagaimana hadis yang di riwayat imam al-Bukhari rahimahullah:

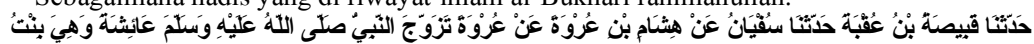

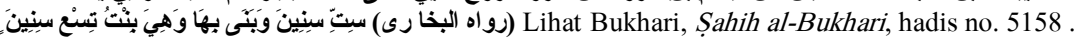

Pendapat lain mengatakan bahwa umur 6 memasuki tahun ke 7, baca selengkapnya Ibn Hajar, al-Iṣabah fī al-Tamyiz as-Ṣahābah, Cet. I, Juz VIII, (Beirūt, Dār al-Kutub al-'Ilmiyyah, 1995), 232.

${ }^{30}$ Islamedia,”Usia Pernikahan “Aisyah dengan Nabi Muhammad”, diakses pada 19 Mei 2013 melalui http://www.islamedia.web.id/2013/03/usia-pernikahan-aisyah-dengan-nabi.html.

${ }_{31}$ Keterangan kaidah ini dapat di lihat Ahmad Al-Raysuni dan Muhammad Jamal Barut, Ijtihal al-Nā̄, al-Waqi'i, al-Mașlahah, (Damaskus: Dar al-Fikr, 2000). Terjm, Ibnu Rusydi dan Hayyin Muhdzar,Ijtihad antara Teks, Realitas dan Kemaslahatan Sosial, (Jakarta: Erlangga, 2002), 46-47.

${ }^{32}$ Beberapa bentuk reforn dalam KHI dapat di lihat pada buku karangan Abdul Manan, Reformasi Hukum Islam di Indonesia, (Jakarta: Raja Grafindo Persada, 2006), 295.
}

138 | INDO-ISLAMIKA, Volume 2, Nomor 1, 2012/1433 


\section{Wali Nasab Enggan, Hakim Memutus Wali Hakim}

\section{Deskripsi Kasus}

Untuk menunjukkan kasus permohonan wali 'aḍal ini, berdasarkan hasil temuan penulis di Pengadilan wilayah DKI Jakarta dari tahun 2010-2011 dapat dilihat pada tabel berikut ini:

Tabel: 4.4.

Perkara Permohonan Wali 'aḍalyang diterima dan diputus Pengadilan Agama DKI Jakarta Tahun 2010-2011

\begin{tabular}{|l|l|l|l|}
\hline No & $\begin{array}{l}\text { Pengadilan Agama DKI } \\
\text { Jakarta }\end{array}$ & $\begin{array}{l}\text { Perkara Di } \\
\text { terima }\end{array}$ & $\begin{array}{l}\text { Perkara Di } \\
\text { putus }\end{array}$ \\
\hline 1 & Jakarta Utara & 4 & 3 \\
\hline 2 & Jakarta Selatan & 21 & 13 \\
\hline 3 & Jakarta Timur & 14 & 8 \\
\hline 4 & Jakarta Pusat & 6 & 2 \\
\hline 5 & Jakarta Barat & 14 & 12 \\
\hline Jumlah & & 59 & 34 \\
\hline
\end{tabular}

Sumber: Pribadi Dari Laporan Tahunan Pengadilan Agama DKI Jakarta Tahun 2010-2011. ${ }^{33}$

Tabel di atas menunjukkan bahwa dari tahun 2010 sampai 2011 permohonan wali 'aḍal yang diajukan ke Pengadilan Agama di seluruh DKI Jakarta mencapai 59 kasus, 34 kasus sudah kabulkan, sedangkan sisanya dalam proses persidangan. Dari keseluruhan permohonan wali 'adal yang diajukan ke Pengadilan Agama hampir 99\% dikabulkan, ${ }^{34}$ dan inti dari masing-masing putusan tersebut tidak ada perbedaan yang begitu mencolok. Hal ini dapat dilihat pada putusan-putusan di bawah ini.

\footnotetext{
${ }^{33}$ Lihat Sufyan, "Laporan Tahunan 2010 Pengadilan Agama Kelas I.A Jakarta Utara tentang Perkara yang diterima dan diputus" (Jakarta, 31 Desember, 2010). Lihat pula Sufyan, "Laporan Tahunan 2011 Pengadilan Agama Kelas I.A Jakarta Utara tentang Perkara yang diterima dan diputus", (Jakarta, 31 Desember 2011). Lihat Ach Jufri dan Ahmad Majid, "Laporan Perkara yang diterima dan diputus Pengadilan Agama Jakarta Pusat Bulan Januari-Desember Tahun 2010". Lihat Ujang Mukhlis, "Laporan Perkara yang diterima dan diputus Pengadilan Agama Jakarta Pusat Bulan Januari-Desember Tahun 2011". LIhat Ach Jufri, “ Laporan Pengadilan Agama Jakarta Selatan tentang Perkara yang diterima dan diputus Tahun 2010”, (Jakarta, 30 Desember, 2010). Lihat Ahmad Majid, "Laporan Pengadilan Agama Jakarta Selatan tentang Perkara yang diterima dan diputus Tahun 2011", (Jakarta, 30 Desember, 2011). Lihat Arsip "Data Perkara Pengadilan Agama Jakarta Barat Tahun 2010", 27-29. Lihat Arsip "Data Perkara Pengadilan Agama Jakarta Barat Tahun 2011", 14-18. Lihat http://www.infoperkara.Badilaq.go.id. Di akses pada tanggal 2 Agustus 2011.

${ }^{34}$ Wawancara dengan M. Rizal (hakim Pengadilan Agama Jakarta Barat), di ruang hakim. tanggal 18 Juli 2012.
} 
Putusan pertama, kasus yang dialami oleh seorang pemohon ${ }^{35}$ berusia 24 tahun, telah mengajukan surat permohonan wali 'adal ke Pengadilan Agama dengan register perkara No. 91/Pdt.P/2011/PA.JB. Dalam positanya dijelaskan bahwa hubungan pemohon dengan calon suaminya (umur 31 tahun) sudah sedemikian erat dan sulit untuk dipisahkan. Calon suami pemohon telah meminang, namun ayah kandung pemohon tidak merestui bahkan menolak untuk menikahkan pemohon dengan calon suaminya dengan alasan calon suami pemohon belum mapan secara finansial. Ayah pemohon bersedia menikahkan anaknya setelah berusia 28 tahun dan sudah hidup mapan secara ekonomi. Pemohon dan calon suaminya berusaha keras dengan melakukan pendekatan dan penjelasan terhadap ayah kandung pemohon agar bersedia menikahkan pemohon, namun tidak berhasil. Pemohon tetap bertekad untuk melangsungkan pernikahan karena dikhawatirkan melakukan hal-hal yang dilarang agama. ${ }^{36}$

Setelah melalui proses persidangan yang cukup panjang dengan menghadirkan para pihak dan saksi-saki, fakta dipersidangan menunjukkan bahwa benar calon suami pemohon telah meminang pemohon untuk dinikahkan, namun wali pemohon menolak untuk menikahkan, padahal keduanya sudah saling cinta dan tidak dapat dipisahkan lagi. Keduanya telah memenuhi syarat pernikahan yakni antara pemohon dengan calon suami terpenuhi dan tidak ada larangan syar' $\bar{i}$ untuk melangsungkan pernikahan. Calon suami pemohon telah mempunyai pekerjaan tetap dan mempunyai penghasilan yang cukup untuk menghidupi pemohon. Antara pemohon dan calon suami pemohon berstatus bujang dan gadis. Setelah mengungkapkan beberapa pertimbangan, majelis hakim meenetapkan wali 'aḍal dan menunjuk Kepala Kantor Urusan Agama di tempat wilayah pemohon.

Putusan kedua merupakan putusan untuk kasus yang melibatkan pemohon, seorang karyawati, umur 28 tahun, pendidikan S1. Ia mengajukan surat permohonan wali 'aḍal ke Pengadilan Agama pada tanggal 14 Februari 2012 dengan register perkara No. 12/Pdt.P/2012/PA JB.

Dalam positanya dijelaskan bahwa, pemohon dalam waktu dekat hendak melangsungkan pernikahan dengan seorang laki-laki berumur 39 tahun, lulusan SMA, pekerjaan karyawan. Hubungan antara pemohon dengan calon suami sudah sangat dekat dan sulit untuk dipisahkan karena sudah kenal lama dan mulai dekat sejak tahun 2006. Calon suami pemohon sudah pernah melamar pemohon melalui orang tua pemohon sebanyak 2 (dua) kali, namun lamaran tersebut tidak diterima sama sekali oleh orang tua pemohon dengan alasan

\footnotetext{
${ }^{35}$ Identitas disembunyikan

${ }^{36}$ Lihat Arsip Pengadilan Agama Jakarta Barat tentang Putusan Penetapan wali 'aḍl No. 91/Pdt.P/2011/PA.JB.
}

140 | INDO-ISLAMIKA, Volume 2, Nomor 1, 2012/1433 
perbedaan status pendidikan dan pekerjaan. Pemohon berpendapat penolakan ayah kandung pemohon tersebut tidak berdasar dan mengada-ngada, serta tidak mendukung kebahagiaan pemohon sebagai anak kandungnya. Oleh karena itu pemohon tetap bertekad untuk melangsungkan pernikahan dengan calon suami pemohon dengan alasan keduanya sama-sama dewasa dan siap mengarungi rumah tangga. Pemohon sangat khawatir apabila antara pemohon dengan calon suami tidak segera melangsungkan pernikahan akan terjadi hal-hal yang bertentangan dengan ketentuan hukum Islam.

Dalam proses persidangan ayah kandung pemohon tidak menghadiri persidangan, walaupun telah dipanggil secara resmi dan patut berdasarkan Relaas Nomor 12/Pdt.P/2012/PAJB yang dibacakan di persidangan. Kemudian dibacakan surat permohonan pemohon, yang isinya tetap dipertahankan oleh pemohon. Berdasarkan bukti-bukti dan saksi-saksi yang dihadirkan dipersidangan menunjukkan bahwa memang benar ayah kandung pemohon menolak menikahkan pemohon dengan calon suaminya dengan alasan perbedaan status pendidikan dan pekerjaan.

Setelah mempertimbangkan banyak hal dan meneliti secara seksama dalildalil yang diajukan pemohon dan bukti-bukti dipersidangan, Majelis hakim mengabulkan permohonan pemohon; dan menunjuk Kepala Kantor Urusan Agama di tempat wilayah pemohon.

\section{Dasar dan Petimbangan Hakim}

Dari amar penetapan yang telah disebutkan di atas, dapat dipertanyakan, apakah penetapan tesebut sesuai dengan peratuan peundang-undangan atau menyimpang dari ketentuan yang berlaku?. Untuk menjawab pertanyaan ini dibutuhkan analisa ilmiah untuk dikembangkan menjadi konsep-konsep pengesahan pemohonan wali 'adal.

Kewenangan hakim dalam memeriksa, memutus dan menetapkan perkara harus dilihat apakah berdasarkan kewenangan absolut dan relatif sesuai dengan kewenangannya atau tidak. Dilihat dari kompetensi Peradilan, wali 'adal termasuk dalam kompetensi absolut ${ }^{37}$ Peradilan Agama. Kompetensi pengadilan di lingkungan Pengadilan Agama diatur dalam Pasal 2 UU No. 7 tahun 1989 yang diubah dengan UU No. 3 tahun 2006 perubahan kedua atas UU No.50 tahun 2009 tentang Peradilan Agama. Pasal tersebut berasaskan personalitas yang menyebutkan bahwa, Peradilan Agama merupakan salah satu kekuasaan kehakiman bagi rakyat pencari keadilan yang beragama Islam

\footnotetext{
${ }^{37}$ Kompetensi Absolut adalah Pengadilan yang berhubungan dengan jenis perkara, misalnya pengadilan berkuasa memeriksa perkara bagi mereka yang beragama Islam, sedangkan bagi yang beagama selain Islam menjadi kekuasaan pengadilan umum. Lihat Raihan A Rasyid, Hukum Acara Peradilan Agama (Jakarta: Raja Gafindo Persana, 2006), 27.
} 
mengenai perkara-perkara tertentu yang diatur dalam pasal 49 ayat (1) UU No. 3 tahun 2006 jo UU No. 50 tahun 2009 yaitu bidang penikahan, waris, wasiat, hibah, wakaf, zakat, infak, sadaqoh, dan ekonomi shari'ah. Dilihat dari kompetensi relatif, ${ }^{38}$ para pemohon sudah melakukan prosedur sesuai dengan hukum acara yakni permohonan mengajukan ke pengadilan yang wilayah hukumnya meliputi kediaman pemohon. ${ }^{39}$ Berdasarkan kompetensi absolut dan kompetensi relatif, hakim berhak memeriksa dan memutuskan atau menetapkan perkara tesebut.

Dari ketiga putusan yang telah diuraikan di atas, jelas bahwa wali menyatakan enggan menikahkan putrinya, baik yang menyatakan penolakan itu di hadapan persidangan maupun di luar persidangan. Sesuai dengan ketentuan hukum acara Peradilan Agama yang menyatakan apabila pihak wali sebagai saksi utama telah dipanggil secara resmi dan patut, namun tidak hadir sehingga tidak dapat didengar keterangannya, maka hal ini dapat memperkuat keberadaan wali 'aḍalnya. ${ }^{40}$ Sebagaimana kasus No. 12/Pdt.P/2012/PA JB dan No.68/Pdt.P/2010/PAJP yang telah dijelaskan sebelumnya. Dalam hal ini untuk memberikan kepastian hukum bagi kedua calon mempelai, majelis hakim memeriksa perkara tersebut dan setelah mempertimbangkan berbagai fakta dalam persidangan, majelis hakim mengabulkan ketiga permohonan tersebut.

Salah satu wewenang Pengadilan Agama adalah memberikan pelayanan hukum dan keadilan bagi mereka yang beragama Islam, maka dasar dan pertimbangan yang digunakan untuk menyelesaikan suatu perkara adalah hukum Islam. Seorang wali ditetapkan menjadi 'adal, jika Pengadilan Agama melihat alasan penolakan wali tersebut dibenarkan secara shari' atau tidak. Selain itu Pengadilan Agama juga mempertimbangkan kemaslahatan dan kemudhorotan yang akan timbul dari putusannya itu.

Pertimbangan hakim dalam memutuskan perkara tersebut untuk menghindari kemudhorotan yang bisa timbul dari perkara tersebut sesuai dengan kaidah الضراريزال (bahaya itu harus dihilangkan). Apabila perkara tersebut tidak dikabulkan, dikhawatirkan akan terjadinya nikah lari atau bahkan "kumpul kebo" hal ini tentunya tidak sesuai dengan ajaran agama.

\footnotetext{
${ }^{38}$ Kewenangan relatif adalah kekuasaan atau wewenang yang diberikan kepada pengadilan dalam lingkungan peradilan yang sama jenis dan tingkatan yang berhubungan dengan wilayah hukum Pengadilan dan wilayah tempat tinggal atau tempat kediaman atau domisili pihak yang berperkara. Kompetensi relatif ini pada dasarnya berkaitan dengan wilayah hukum suatu pengadilan. Lihat Muchinum, Komptensi Peradilan Agama Relatif dan Absolut dalam Kapita Selekta Hukum Perdata Agama dan Penerapannya (Bogor: Pusdiklat Teknis Bailtbang Diklat Kumdil MARI, 2008), 127. Lihat pula Badriyah Harun, Tata Cara Menghadapi Gugatan (Yogyakarta: Pustaka Yustisia, 2009), 52-54.

${ }^{39}$ A. Mukti Arto, Praktek Perkara Perdata pada Pengadilan Agama (Yogyakarta: Pustaka Pelajar, 1996), 44.

${ }^{40}$ A. Mukti Arto, Praktek Perkara Perdata pada Pengadilan Agama, 238.
}

142 | INDO-IsLAMIKA, Volume 2, Nomor 1, 2012/1433 
Dasar yang digunakan majelis hakim untuk menetapkan 'aḍahya wali adalah bukti-bukti serta fakta-fakta hukum yang berkaitan dengan perkara tersebut. Hal ini sesuai dengan pasal 163 HIR yang menyatakan bahwa:

"Barang siapa yang mengatakan ia mempunyai hak, atau ia menyebutkan suatu perbuatan untuk menguatkan haknya itu, atau untuk membantah hak orang lain, maka orang itu harus membuktikan adanya hak itu atau adanya kejadian itu. ${ }^{41}$

Bukti yang harus disertakan berupa bukti surat dan saksi. Bukti surat yang pokok dalam perkara wali 'aḍal adalah surat penolakan pernikahan yang dikeluarkan oleh Kantor Urusan Agama setempat (P.I). Sedangkan saksi adalah orang-orang yang mengetahui adanya permasalahan tersebut, dan saksi-saksi dimintai keterangan mengenai keengganan wali dan juga keadaan kedua calon mempelai berdasarkan yang dilihat, yang didengar dan yang dialami oleh para saksi tersebut. ${ }^{42}$ Sesuai pasal 169 menyatakan saksi minimal dua orang, satu saksi bukan saksi (Unus Testis Nulus Testis). ${ }^{43}$

Untuk menetapkan wali hakim sebagai wali nikah dari perempuan yang wali nasabnya 'adal, Pengadilan Agama mendasarkan pada Peraturan Menteri Agama No. 2 Tahun 1987 tentang wali hakim dan pasal 23 KHI. Kedua peraturan tersebut tidak selalu dijadikan dasar hukum penetapan wali 'adal, terkadang hakim menggunakan Peraturan Menteri Agama saja, hal ini dapat di lihat pada perkara No. 91/Pdt.P/2011/PA.JB. Sebenarnya sah saja hakim hanya merujuk pada Peraturan Menteri Agama tentang wali hakim, namun menurut penulis seyogyanya hakim juga merujuk pada KHI untuk mempertajam penetapan tersebut. Alasan hakim tidak merujuk pada KHI sebagai dasar pertimabangan wali 'adol bisa jadi karena KHI tidak termasuk dalam hirarki perundang-undangan, sesuai pasal 7 ayat (1) UU No. 10 tahun 2004 jenis dan hirarki peraturan perundnag-undangan adalah, (1) Undang-Undang Dasar Negara Republik Indonesia1945. (2) Undang-Undang/Peraturan Pemerintah Pengganti Undang-Undang (Perpu). (3) Peraturan Pemerintah. (4) Peraturan Presiden. (5) Peraturan Daerah. Meskipun demikian, dasar hukum hakim dalam penetapan wali 'aḍal senantiasa dilengkapi dengan pendapat para fuqaha' yang tertera dalam kitab-kitab fikih.

Ada banyak faktor penyebab orang tua enggan menjadi wali. Secara global dalam status sosial tidak sekufu, baik itu mengenai status ekonomi, suku, pendidikan dan lain sebagainya. ${ }^{44}$ Status sosial di sini umumnya terjadi

\footnotetext{
${ }^{41}$ R. Soesilo, RIB/HIR dengan Penjelasan, (Bandung: Karya Nusantara,1979), 119.

${ }^{42}$ A. Mukti Arto, Praktek Perkara Perdata pada Pengadilan Agama,161.

${ }^{43}$ A. Mukti Arto, Praktek Perkara Perdata pada Pengadilan Agama, 164.

${ }^{44}$ Wawancara dengan M. Rizal (hakim Pengadilan Agama Jakarta Barat), di ruang hakim. tanggal 18 Juli 2012.
} 
jika status sosial perempuan lebih tinggi dari status sosial laki-laki. Orang tua beranggapan jika anak gadisnya menikah dengan laki-laki yang statusnya lebih rendah, maka hanya membuat malu keluarga. Orang tua merasa harkat dan martabatnya turun, sebagaimana penetapan perkara No. 91/Pdt.P/2011/PA.JB. Tidak sekufu dalam bidang pendidikan juga kerap kali menjadi faktor penyebab orang tua enggan menjadi wali sebagaimana perkara No. 12/Pdt.P/2012/PA JB.

Pada umumnya orang tua memperhatikan dengan seksama mengenai status calon menantunya, yang menjadi pertimbangan, apakah jejaka atau duda. Jika duda pun, masih dipertimbangkan, duda cerai atau duda mati. Masalah yang kerap terjadi jika calon suami anak tersebut akan menikah dengan duda cerai. Umumnya orang tua masih sulit menerima jika calon menantunya adalah duda cerai, apalagi jika anaknya masih gadis. Kecurigaan dan kekhawatiran pasti muncul seputar penyebab perceraian, bagaimana jika kelak anaknya juga menjadi korban perceraian dan lain sebagainya, sebagaimana permohonan No.68/Pdt.P/2010/PAJP.

Dari uraian di atas, jelas bahwa wali pemohon tidak menggunakan haknya, dan berarti wali pemohon harus dinyatakan 'aḍol, hal ini dikuatkan juga dengan ketidak hadiran wali dalam persidangan sebagaimana perkara No. 12/Pdt.P/2012/PAJB, dan perkara No.68/Pdt.P/2010/PAJP. Dalam hal ini wali tersebut dinyatakan zalim, karena penolakannya tersebut tanpa alasan yang bisa diterima syara'. Berbeda halnya jika penolakan wali dikarenakan suatu alasan yang dapat diterima syara', maka penolakan seorang wali itu tidak menjadikannya sebagai wali 'ạ̣al.

Dalam hal ini hakim memutus perkara tersebut dengan seadil-adilnya, sebagaimana setiap putusan atau penetapan hakim harus bernilai keadilan, kemanfaatan dan kepastian hukum. Secara umum hakim telah tepat dalam memutuskan perkara wali 'aḍal, hal ini terlihat dari dasar dan pertimbangan hakim yang merujuk pada peraturan perundang-undangan yang berlaku dan dilengkapi dengan pendapat para ulama' dalam kitab-kitab fikih.

\section{Penutup}

Hukum keluarga Islam di Indonesia yang terdapat dalam UU No.1/1974 dan KHI telah berupaya memberi perlindungan terhadap hak-hak anak perempuan dalam kehidupan keluarga. Hal ini dapat dilihat adanya peraturan mengenai dispensasi nikah dan wali 'adal. Pada kurun waktu 2010 sampai 2011, permohonan dispensasi nikah yang diterima di Pengadilan Agama DKI Jakarta mencapai 41 kasus. Dari sejumlah kasus tersebut, 36 kasus sudah disidangkan dan diputuskan. Para hakim cenderung memberi ijin untuk pasangan untuk melakukan pernikahan dengan beberapa alasan yang praktis dan kemaslahatan yang secara nyata dan langsung diterima oleh pasangan dan 
pihak terkait. Alasan bahwa mereka, ketika diberikan ijin melakukan pernikahan dalam usia muda, akan kehilangan kesempatan menempuh pendidikan sering diabaikan.

Terkait dengan kasus wali nasab yang menolak untuk menikahkan anakanak perempuan mereka, para hakim mempunya sikap yang sama, cenderung memberikan ijin dan memutuskan menunjuk wali lain sebagai wali hakim. Faktanya dari tahun 2010 sampai 2011 permohonan wali 'aḍal yang diajukan ke Pengadilan Agama di seluruh DKI Jakarta mencapai 59 kasus, 34 kasus sudah kabulkan, sedangkan sisanya dalam proses persidangan. Dari keseluruhan permohonan wali 'aḍl yang diajukan ke Pengadilan Agama hampir 99\% dikabulkan. Berdasarkan hasil putusan-putusan Pengadilan Agama menunjukkan bahwa, mayoritas permohonan dispensasi nikah disebabkan kasus kehamilan di luar nikah. Kondisi ini mengharuskan Majelis hakim mengabulkan permohonan tersebut demi kemaslahatan semua pihak.

\section{Daftar Pustaka.}

Abdurrahman. Kompilasi Hukum Islam. Jakarta: Akademika Pressindo, 1995.

Arsip "Data Perkara Pengadilan Agama Jakarta Barat Tahun 2010."

Arsip "Data Perkara Pengadilan Agama Jakarta Barat Tahun 2011."

Arto, A. Mukti. Praktek Perkara Perdata pada Pengadilan Agama. Yogyakarta: Pustaka Pelajar, 1996.

Departemen Agama. Undang-undang Nomor 1 Tahun 1974 tentang Pernikahan. Jakarta: Proyek Penyuluhan Hukum Agama, 1995.

Dimsyiqi, Al. Kifayah al-akhyār. Bairūt: Dār al Fikr, t.th.

Dokumen Putusan Pengadilan Agama Jakarta Barat Nomor 33/Pdt.P/2012/PAJB.

Dokumen Putusan Pengadilan Agama Jakarta Pusat Nomor 19/Pdt.P/2010/PAJP.

Dokumentasi Pengadilan Agama Jakarta Barat tentang Putusan Penetapan Wali 'Aḍal No. 91/Pdt.P/2011/PA.JB.

Dokumentasi Pengadilan Agama Jakarta Pusat tentang Putusan Penetapan Wali 'Aḍal No. 68/Pdt.P/2010/PAJP.

Dokumentasi Pengadilan Agama Jakarta Pusat tentang Putusan Penetapan Wali 'Aḍal No. 12/Pdt.P/2012/PA JB.

Eckholm Erick dan Kathleen Newland, Perempuan, Kesehatan Keluarga dan Keluar Berencana. Perjm. Masri Maris dan Ny. Sukanto. Jakarta: YOI dan Sinar Harapan, 1984.

Fariha Aryani, "Pemberian Dispensasi Terhadap Perkawinan Perempuan Usia

Dini dalam Keadaan Hamil dan Akibat Hukumnya Pada Pengadilan 
Agama Bantul". Yogyakarta: Fakultas Hukum Universitas Islam Indonesia, 2011.

Hadikusuma, Hilman. Hukum Pernikahan Indonesia Menurut Menurut Perundangan, Hukum Adat dan Hukum Agama. Bandung: Bandar maju, 2007.

Harun, Badriyah. Tata Cara Menghadapi Gugatan, Yogyakarta: Pustaka Yustisia, 2009.

Hoerudin, Ahrum. Pengadilan Agama. Bandung: Citra Aditya Bakti, 1999.

Hokker, M. B. Undang-undang Islam di Asia Tenggara. Kuala Lumpur: Ampang Press, 1992.

http://www.infoperkara.Badilaq.go.id. Di akses pada tanggal 2 Agustus 2011.

IIn Wahyuni, "Dasar dan Pertimbangan Hakim Mengabulkan Dispensasi Usia

Pernikahan (Studi di Pengadilan Agama Kota Malang”. Malang: Fakultas Hukum Universitas Brawijaya, 2009.

Irianto, Sulistyo. Perempuan dan Hukum. Jakarta: Yayasan Obor Indonesia, 2006.

Iskandar Ritonga, "Hak-hak Perempuan dalam Hukum Kekeluargaan Islam di Indonesia: Implementasinya dalam Putusan-putusan Peradilan Agama DKI Jakarta, 1990-1995”. Jakarta: UIN Syarif Hidayatullah Jakarta, 2002.

Jazairi, Al, 'Abd al- Rahman. al-Fiqh 'alā al-Madhāhib al-'Arba'ah, Jilid V. Bairūt: Dār al-Fikr, 1990.

Jufri Ach dan Ahmad Majid. "Laporan Perkara yang Diterima dan Diputus Pengadilan Agama Jakarta Pusat Bulan Januari-Desember Tahun 2010".

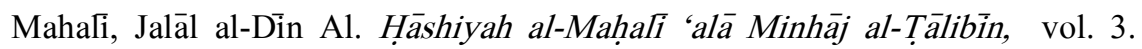
Semarang: Thahā Putra, t.th.

Majid, Ahmad. "Laporan Pengadilan Agama Jakarta Selatan tentang Perkara yang Diterima dan Diputus Tahun 2011”. Jakarta, 30 Desember, 2011.

Mukhlis, Ujang. "Laporan Perkara yang diterima dan diputus Pengadilan Agama Jakarta Pusat Bulan Januari-Desember Tahun 2011".

Muchinum, Kompetensi Peradilan Agama Relatif dan Absolut dalam Kapita Selekta Hukum Perdata Agama dan Penerapannya, Bogor: pusdiklat Teknis Balitbang Diklat Kumdil MARI, 2008

Nasution, Khoiruddin. Islam: Tentang Relasi Suami Dan Istri (Hukum Pernikahan I, Cet. I. Yogyakarta: Academia Tazzafa, 2004.

Rafiq, Ahmad. Hukum Islam di Indonesia. Jakarta: Rajawali Pers, 1995

Rasyid, Ar. Raihan. Hukum Acara Peradilan Agama. Jakarta: Raja Gafindo Persana, 2006.

Sayis, M. Ali Al dan Mahmud Syaltout. Perbandingan Mazhab dalam Masalah

Fiqh,Trans, Ismuha, Cet. ke VI. Jakarta: Bulan Bintang.

Singarimbun, Masri. Penduduk dan Perubahan. Yogyakarta: Pustaka Pelajar.

146 | INDO-ISLAMIKA, Volume 2, Nomor 1, 2012/1433 
Perempuan Sebagai Anak dan Hak-haknya dalam Perkawinan (Studi Terhadap Peraturan Perundang-undangan dan Praktek di Pengadilan Agama)

Soemiyati. Hukum Pernikahan Islam dan Undang-undang Pernikahan. Yogyakarta: Liberty, 1986.

Sosroatmodjo, Arso dan Wasit Aulawi. Hukum Pernikahan di Indonesia. Jakarta: Bulan Bintang, 1975.

Sudirman. "Pembatasan Usia Minimal Pernikahan: Upaya Meningkatkan Martabat Perempuan". Malang: Fakultas Syariah UIN Malang.

Sudirman. "Pembatasan Usia Minimal Pernikahan: Upaya Meningkatkan Martabat Perempuan". Malang: Fakultas Syariah UIN Malang.

Sufyan. "Laporan Tahunan 2010 Pengadilan Agama Kelas I.A Jakarta Utara tentang Perkara yang diterima dan diputus”. Jakarta, 31 Desember, 2010. "Laporan Tahunan 2011 Pengadilan Agama Kelas I.A Jakarta Utara tentang Perkara yang diterima dan diputus", (Jakarta, 31 Desember 2011).

Sulaki-lakidi, Dedi dan Mustofa. Perbandingan Hukum Pernikahan di Dunia Islam. Bandung, Pustaka al-Fikriis, 2009.

Syarifuddin, Amir. Hukum Pernikahan Islam di Indonesia Jakarta: Kencana, 2006.

Syarifuddin, Amir. Pembaharuan Pemikiran dalam Hukum Islam. Padang: Angkasa Raya, 1990.

Undang - undang Nomor 23 Tahun 2002 tentang Perlindungan Anak, 2- 4.

Wahid, Abdurrahman. Kontroversi Pemikiran Islam di Indonesia. Bandung, Rosda Karya, 1991.

Wahyudi, Muhamad Isna. "Menekan Tingkat Pernikahan Anak", diakses pada 1 Juli 2012 melalui http://www.nu.or.id/a,public-m,dinamic-s,detail-ids,4id,37162-lang,id-c,kolomt,Menekan+Tingkat+Pernikahan+Anak-.phpx.

Zuhaili, Wahbah Al. al-Fiqh al-Islām wa-'Adillatuh. Damaskus: Dār al-Fikr, 2004.

Wawancara dengan M. Rizal, Hakim Pengadilan Agama Jakarta Barat, tanggal 18 Juli 2012. 